\title{
CONTRIBUTION OF BEHAVIOURAL ECONOMICS TO EXPLANATION OF GENDER WAGE LEVEL DIFFERENCES
}

\section{Dagmar Brožová*}

\begin{abstract}
There is still a significant gender wage gap on labour markets in the majority of developed countries. The different earnings are determined mainly by the different sectors, professions and positions that men and women choose. The behavioural approach to interpretation of the labour market agents' decisions can help to explain the choice of different working career paths. The approach focuses on subjective individual preferences and their intrinsic rewards and motivations that cannot be explained by objective rational rules.

The paper confirms the different relation of men and women to risk and competition and different preferences to intrinsic and extrinsic motivations and rewards. The author's existing research on Czech data is used. Women indeed preferred a lower risk, although the difference was not large ( -0.7 points on a scale of $0-10)$, while gender does not matter for people with university education. The level of accepted risk was increased by education, career preferences, pride and partnership. On the contrary, having children and their number did not affect the level of accepted risk. As far as extrinsic and intrinsic rewards and motivations were concerned, the preference for intrinsic rewards was higher among women (44\%) than men (31\%). Women preferred intrinsic rewards compared to higher wages more likely than men. Women with university education preferred intrinsic rewards with the same probability as men with the same degree of education. The preference of non-monetary rewards and motivation increased with higher education.
\end{abstract}

Keywords: rational choice model, behavioural model of the human agent, risk preference, social preference, intrinsic rewards, extrinsic rewards

JEL Classification: D91, J16

\section{Introduction}

There is still a persisting significant gender wage gap on the labour market, and this is in the majority of developed countries. Although the human capital of men and women converges over time, women gradually catch up with men in terms of participation in the labour market and countries have anti-discrimination legislation. The different earnings are determined primarily by the different sectors, professions and positions that men and women are choosing (Goldin, 2014; Blau and Kahn, 2016). This is usually preceded by different gender choices of the branch of study. Men are more likely to choose IT, finance or law, where high wages can usually be achieved, while women tend to choose to study humanities in particular where wages are much lower.

Dagmar Brožová, University of Economics, Prague, Czech Republic (dagmar.brozova@vse.cz). 
It is precisely the fact that men and women choose a different career in the labour market that can help to explain the behavioural approach to interpretation of labour market agents' decision-making. It focuses on subjective individual preferences and their intrinsic motivation, which cannot be explained by objective rational rules. Conversely, the behavioural approach turns to psychological, internal motives of human action. This approach is reflected in the different profiling of the market agent himself, whose behaviour and decision-making is subjected to analyses.

In this paper, I will focus on the following three determinants that are considered in the literature as highly relevant in relation to outputs on the labour market from the gender perspective: the different relationship of men and women towards risk, a different relationship to competition, and the preference of different motivations and rewards and related social preferences. Croson and Gneezy (2009), Schurkov and Eckel (2017) also add distinctions in willingness and ability to negotiate.

Papers and studies are consistent in the finding that men prefer external motivation and rewards (extrinsic rewards), in particular monetary, such as wage, while women prefer internal rewards and motivations (intrinsic rewards), or non-monetary ones (Tolbert and Moen, 1998; Miles, 2013). Basically, they agree that women are on on average more risk averse, have a lower level of ability to succeed in competition and willingness to compete, and also have a lower willingness and ability to negotiate (e.g., on the wage level) than men; on the contrary, they are more receptive and responsive to the social environment.

The purpose of the contribution is to explain the influence of the different relationship of men and women to risk, different relationship to competition and the differing preferences of internal and external motivations and rewards on the gender choices on the labour market and their confrontation with the author's original existing research on data from the Czech Republic.

\section{Market Agent versus Human Agent}

The central concept of the neoclassical paradigm is the rational choice model, the subject of which is a market agent. In the neoclassical labour market economics, a market agent is represented by "homo economicus", who acts and decides rationally in a market environment that is externally legally and institutionally defined. The market agent is able to obtain the necessary information and its action is purposeful. Its goals are determined by one's own preferences, strictly based on one's own needs. In the spirit of methodological individualism, everyone maximizes his own benefit, which can be both monetary and non-monetary. People have consistent, stable preferences, organized according to their importance, but independent of the behaviour and experience of other people, or past or future consumption. Since people are confronted with the scarcity of resources (income, time) while satisfying their needs, people consider the benefits and costs of each alternative, and realize a choice that maximizes their utility satisfaction in every moment (utility maximization problem). Such an image of a market agent corresponds to the effort of high formalization and axiomatization, and at the same time the maximum reduction 
of psychological or social aspects of his action. Human internal mental qualities (sources of need and order of preferences, cognitive process, motivation of action) or social relations are a "black box" here (Kaufman, 1999).

In the last decades, there is an obvious renewal of interest in the behavioural economics. ${ }^{1}$ This interest was also supported by Becker; in his Nobel lecture, he supported the expansion of the traditional analysis of individual rational choice in order to take into account a higher level of attitudes, preferences and calculations (Becker, 1993). Later he included social standards into the microeconomic model and named this ability social capital (Becker, 1996).

The neoclassical model is based on given, unchanging preferences that result from the subjective needs of man. If something changes, it is the environment, such as incomes or prices (extrinsic motivation) that affect its budget limits. Real changes in the preferences have recently been an argument for the expansion of psychological factors into economic theory. This involves the inclusion of the human agent's psychological model in economics and hence its wider interdisciplinary research and cooperation with other scientific disciplines (psychology, sociology). His decisions and behaviour can be motivated by his psychological motives and characteristics (intrinsic motivation). Bowles calls it a "behavioural trait" (Bowles, 2001). The standard model of a market agent is perceived as simplified and incomplete from this viewpoint. Nevertheless, his critics acknowledge to it the status of the basic starting model, which needs to be supplemented and expanded to improve its explanatory ability.

The behavioural model of the human agent is based on the fact that people are led by their own interests, but make decisions under conditions of limited rationality and imperfect information. Individual agents have limited intelligence and the lack of rationality is replaced by other abilities, such as emotions, ethical norms, and social relations. The preferences of one person are influenced by the preferences of others with which he is in social contact that forms the social environment and with which he is compared. Preferences also change over time. They are also influenced by the ethical values of society. In this sense, Kaufman $(1999)^{2}$ suggests broadening of the standard market agent model with psychological aspects; in particular, he elaborates three psychological constructs: motivation (they lead behaviour), cognition (mental processes of gathering and processing information) and emotions (subjective mental feelings).

\section{Relation to Risk}

Women have greater aversion to dangers and losses than men, they feel them more strongly. That is why they choose professions with lower risk. This is confirmed by laboratory experiments investigating access to investment or interest in insurance. Using the method of laboratory experiments, Croson and Gneezy (2009) confirmed their hypothesis that women are more risk-averse than men. According to them, single women are more risk-

\footnotetext{
1 In this sense, it is written, e.g., by Akerlof, Lazear, Simon, Sollow or Frank.

2 Kaufman refers to influential works of psychologists Kahneman and Tversky.
} 
averse than single men. Women are more conservative in investing than men; they are more careful, less creative and choose different portfolios than men. More often, they are interested in insurance, which reduces subjectively perceived risk. Explanations are seen in different emotional responses to risky situations; there, women show a greater degree of nervousness in expectations of a negative result than men. This results in low benefits of risky alternatives and creates a different relation of women towards risk, unlike men. Men understand risky situations as a challenge, as an opportunity to exercise their abilities, they are more confident, and that leads to their greater tolerance to risk situations.

This has a significant impact on earnings. Less risky professions, which are more often chosen by women, are generally honoured with lower wages; on the contrary, professions with higher risk levels include the risk premium typically earned by men. If some women are more tolerant to risk, they often find work in the area of finance and law dominated by men (Bertrand et al., 2010) and the difference in earnings is then minimal.

Surveys that focus only on selected groups of workers confirm these statements. Atkinson et al. (2003) compared the investment behaviour of managers and entrepreneurs. They found out that the preference for risk did not differ significantly in terms of gender; the differences were related to investment knowledge or the size of wealth. Johnson and Powel (1994) confirmed a similar conclusion. They investigated the decision-making characteristic for men and women in managerial population (with formal managerial education and managerial position) and non-managerial population (without formal managerial education and no managerial position). In the group of managers, both men and women showed the same willingness to take risks and made decisions of the same quality, while in the non-managerial group, women were more risk-averse than men. The authors interpret these results as a result of free choice of job position. People who prefer risk more than others choose managerial positions because they are ready to face the risk. When women choose this position, they have a similar relationship to risk as men in these positions and make similar decisions. Similar findings are made by Barbulescu and Bidwell (2013): graduates of MBA programmes are ambitious, looking for jobs at a high level of wage and prestige, regardless of gender.

In our original research ${ }^{3}$, we formulated and verified a hypothesis that women are more risk-averse than men and have lower preferences for competitive situations than men. We used the Ordinary Least Squares (OLS) method. The explained variable was the level of accepted risk constructed on the basis of a question that the respondents were asked in the research questionnaire: "How high is the level of risk that you are ready to undergo in your professional career? Place yourself on the following scale from 0 (no risk) to 10 (very high risk)". The subjective statements of respondents are concerned. The economic theory elaborates on these increasingly often recently. The frequency distribution was positively tested as normal.

$3 \quad$ For the detailed description of the estimated models, see Brožová, Stroukal, 2018, Gender Differences in Preference of the Wage Level and Risk on the Czech Labour Market. European Scientific Journal, 14 (4), 73-90. 
The dataset ${ }^{4}$ for this research contained 1984 observations, while the observation unit was chosen as a Czech employee aged between 25 and 54 who worked actively during the survey. The data come from an exclusive questionnaire survey.

The explained variable was the variable Woman with a value of 1 for women and a value of 0 for men and other variables were education, career preference, time spent at work, income, age, partner relationship, pride and other variables describing personal and working characteristics.

The model was estimated in the following form:

Risk level $=\beta_{0}+\beta_{1}$ Woman $_{i}+\beta_{2}$ Secondary education with school diploma ${ }_{i}+$

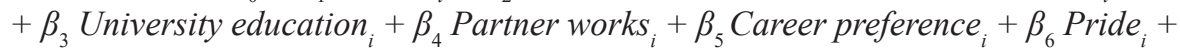

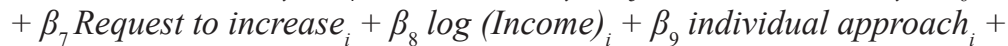

$$
+\beta_{10} \text { Age 25-34 }+\beta_{11} \text { Partner }+u_{i}
$$

As regards the verified hypothesis, we expected that women prefer risk less, so the coefficient $\beta_{1}$ would be significant and negative.

We also worked with a wider version of the model, where we added variables describing a combined influence of gender and university education. This model had the following form:

Risk level $=\beta_{0}+\beta_{1}$ Woman $_{i}+\beta_{2}$ Secondary education with school diploma ${ }_{i}+$ $+\beta_{3}{\text { Partner } \text { works }_{i}+\beta_{4} \text { Career preference }}_{i}+\beta_{5}$ Pride $_{i}+\beta_{6}$ Request to increase $_{i}+$

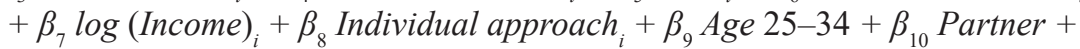
$+\beta_{11}$ Woman with university $_{i}+\beta_{12}$ Man with university $+u_{i}$

Already from the overview of our dataset, it was apparent that the level of accepted risk is lower among women than among men. Although the average evaluation of acceptable risk of the respondents is 5 (on the scale of 10 points), it is 4 for women and 6 for men (see Appendix, Table 1).

The results of the models confirmed (see the Appendix, Table 2) that women indeed preferred lower risk. In a more precise estimation with additional variables combining gender and university education, it was shown that women with lower than university education preferred risk about 0.7 points less than men with comparable education and other comparative characteristics, while women with university preferred risk only 0.2 points less. In comparison with university-educated men, university-educated women prefer risk about 0.6 points less. The bonus for university adds 0.5 points for men and 0.4 points for women to the risk preference.

The level of accepted risk is increased by education, career preferences, and respondents' pride or partner relationship. Younger respondents are rather more willing to assume higher risk. It is interesting that having children and their number do not have an influence on the level of accepted risk. There is also no distinction between respondents of middle age and older ones.

4 The data come from a questionnaire survey and were acquired and processed by a specialized company Trexima for project GAČR 402/11/2464. 


\section{Extrinsic and Intrinsic Motivation and Rewards}

The research suggests that men more than women prefer extrinsic rewards, especially wages, while women prefer intrinsic rewards, which are non-monetary incentives and rewards, e.g., the possibility to work with people (Tolbert and Moen, 1998; Miles, 2013).

Daymont and Andrisani (1984) have clearly confirmed the differences in preferences of men and women. Men felt more than women the opportunity to make money as a very important aspect for job and career choices. They also preferred the opportunity to be a leader. Women identified it as important to help others and to work with people. Also Betz and O'Connell (1989) report that when choosing a job, men more than women focus on income and career progress possibilities. According to Marini et al. (1996), women rated money as a less important feature of a job than men did.

In our research, we formulated two hypotheses: (1) that women would prefer positions with high wages with a lower probability, and (2) that men and women with university education prefer positions with high wages with the same probability. Both hypotheses were confirmed.

As a basic variable for verification of our hypotheses, we created a new variable Intrinsic. This variable had a value of 1 if the respondent answered at least three out of five questions positively, meaning that he answered yes or rather yes. These questions regarded preference of the so-called intrinsic motivations, security of employment (1), flexibility of employment (possibility of home office, part-time, with flexible working hours and so on) (2), possibility of self-realization in employment (3), preference of low stress at work (4) and good interpersonal relationships at work (5) in particular, and always in comparison with the amount of wage. The format of the question was the following: "Which is more important for you - the respective intrinsic motivation or the amount of wage?" If the respondent answered positively at least three questions, we considered him as preferring the intrinsic rewards and motivations.

To verify the two hypotheses, we used the Probit method which allows to estimate the probability that the respondent prefers intrinsic rewards and reflect intrinsic motivations in dependence on a number of variables. The first and the most important is the variable Woman, which takes the value of 1 for women and 0 for men. We netted out the estimation of other variables recording the respondent's education and his further personal and professional characteristics and we got the estimation of the impact of gender itself on the preference of intrinsic rewards for the variable Woman, while we estimated that this impact would be positive.

To verify the first hypothesis, we formed the following model:

$P\left(\right.$ Intrinsic $\left._{i}=1 \mid x\right)=\beta_{0}+\beta_{1}$ Woman $_{i}+\beta_{2}$ Secondary education $d_{i}+$

$+\beta_{3}$ Secondary education with school diploma ${ }_{i}+\beta_{4}$ University education $_{i}+$

$+\beta_{5}$ Time at Work ${ }_{i}+\beta_{6}$ Partner works ${ }_{i}+\beta_{7}$ Career preference ${ }_{i}+\beta_{8}$ Pride $_{i}+$

$+\beta_{9}$ Request to increase $_{i}+\beta_{10} \log$ (Income $)_{i}+\beta_{11}$ Individual approach ${ }_{i}+u_{i}$

In this model, we expected the coefficient $\beta_{1}$ to be positive and of a significant value, so women would prefer more intrinsic rewards than men. 
To verify the second hypothesis, we added two other variables reporting the combined influence of gender and finished university, so Woman University and Man University, to the first model. This model was estimated in the form:

$$
\begin{aligned}
& P\left(\text { Intrinsic }_{i}=1 \mid x\right)=\beta_{0}+\beta_{1} \text { Woman }_{i}+\beta_{2} \text { Secondary education }_{i}+ \\
& +\beta_{3} \text { Secondary education with school diploma }{ }_{i}+\beta_{4} \text { Time at Work }_{i}+
\end{aligned}
$$

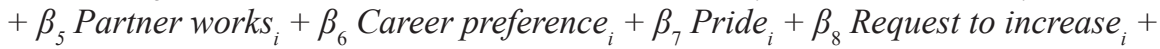

$$
\begin{aligned}
& +\beta_{9} \log (\text { Income })_{i}+\beta_{10} \text { Individual approach }_{i}+\beta_{11} \text { Woman university }_{i}+ \\
& +\beta_{12} \text { Man university }+u_{i}
\end{aligned}
$$

In this model, we considered the second hypothesis as verified if the sum of the coefficients $\beta_{1}+\beta_{11}$ was negative and had the same values as the coefficient $\beta_{12}$. In other words, the hypothesis was confirmed if university-educated women preferred intrinsic rewards less thanks to their education and men also, while gender was not decisive for universityeducated people. If the first hypothesis is true, the discount of preference of intrinsic reward for university education should be higher than the bonus to their preference for the sole gender, so $\beta_{1}<-\beta_{3}$.

The variable Intrinsic was preferred in nearly 37 percent of cases overall; its preference was higher for women (44\%) than for men (31\%). It has been confirmed that the intrinsic rewards are more important for women than for men. Interestingly, the preference of intrinsic rewards grows with higher education. For secondary education (compared to elementary) the difference is $14 \%$, for secondary school graduates $26 \%$ and for university graduates even $37 \%$. Intrinsic rewards are positively related to pride, individual approach and partner presence. For example, if the partner works, then the respondent prefers internal rewards by more than $5 \%$ compared to respondents without a partner, or with a partner who does not work. The influence of having children, their number or the respondent's age was not confirmed.

The preference of higher wages compared to intrinsic rewards has been demonstrated for those respondents who work more hours per week; who prefer a career over the family and respondents with higher incomes.

Among the university-educated respondents, the preference of intrinsic rewards does not differ according to gender; they are preferred more regardless of gender, even by $40 \%$ compared to the respondents without university education. While men and women with university education prefer the level of wages and non-monetary rewards with the same probability, when considering respondents without university, there is a higher wage preference among men.

The social preferences are closely related to this issue. We included them into internal motivations, because one of the questions aimed at the preference of good interpersonal relationships at the workplace. Social preferences can be either inborn or developed over time through various social interactions. They can be modelled as cooperation, altruism, reciprocity. Women are more sensitive to the social environment and, in the case of laboratory experiments, to the context of the experiment (Croson and Gneezy, 2009). Women are more cooperative; for example, they support higher levels of redistribution of incomes than men (Alesina et al., 2011). 
Daymont and Andrisani (1984) tested the importance of four features of a job position: the opportunity to make money, the opportunity to be a leader, the opportunity to help others and the opportunity to work with people. These attributes unambiguously identified the differences in preferences of men and women. Men more than women felt the opportunity to make money as a very important aspect to take the job position. Men much more than women felt the importance of choosing a profession that offers the opportunity to be a leader. The authors have confirmed traditional female preferences to work with people and help others.

Betz and O'Connell (1989) also report that men more than women are more likely to focus on income and career opportunities when choosing a job, while women look for opportunities to use their communication skills and work with people.

Gender differences in social preferences have a significant effect on the choice of profession, with consequent impact on earnings. People with a high level of altruistic preferences more often choose jobs in the public sector. However, employment in the public sector is associated with lower wages but greater security of employment. Jobs directly involving taking care of others are dominated by women, and precisely these jobs (in particular, social services) suffer from a large penalty that reduces their income. Caring workers have the lowest compensations in the economies.

\section{Discussion and Conclusion}

The first important finding is that the results of our models were in compliance with the findings of the reported research. This means that the behaviour of people on the labour market in our country in the surveyed aspects is not different from the behaviour of people on labour markets in other countries.

Women indeed preferred lower risk, although the difference was not great. It has turned out that the level of risk accepted is increased by education, career preferences, pride and partnership. The amount of the accepted risk is not affected by children or their number. As far as extrinsic and intrinsic rewards and motivations were concerned, then men without university education were more likely than women to prefer wages; women with university education preferred intrinsic rewards with the same probability as men with the same degree of education. The difference in gender was not proven. Preference of intrinsic rewards grows with higher education.

All the above findings are a behavioural contribution to explaining different wages that men and women achieve on the labour market. When we ask ourselves how this difference could be reduced using these findings, two approaches are offered: either to teach women to tolerate more risk, to effectively compete and negotiate, or to create a new institutional design of wage formation based on the findings of behavioural economics and psychology research so that differences in wages do not occur or are minimized.

The first option would be further education and training for women. They could take the form of training courses, seminars, workshops and practical exercises, where women would gain additional knowledge to form a more positive relationship to risk and acquire 
effective competences to negotiate and succeed in a competitive environment. The open question here remains how effective this path could be. In other words, to what extent we can change objectively something that is based subjectively and psychologically.

The second approach would be a role for a human resource policy and human resource practice, including wage scale design. An alternative approach to institutional design and the overcoming of established stereotypes is pointed out by Bohnet (2016). According to him, it is a challenge for human resource practice and policy with new evaluations respecting gender differences. This would mean, however, that the rules for recruiting workers and determining their wages would be further removed from market forces and the effective functioning of the labour markets. The direction towards the zero gender wage gap would necessarily reduce the effectiveness of the market system.

\section{Appendix}

Table 1 | Dataset Overview (\%)

\begin{tabular}{|c|c|c|c|}
\hline Characteristic & Population & Women & Men \\
\hline Intrinsic rewards & 37 & 44 & 31 \\
\hline Risk level (0-10) & 5 & 4 & 6 \\
\hline Primary education & 4 & 4 & 4 \\
\hline Secondary education & 74 & 71 & 76 \\
\hline University education & 21 & 24 & 20 \\
\hline Number of hours at work & 42 & 40 & 43 \\
\hline Partner works & 60 & 67 & 53 \\
\hline Career preference & 29 & 22 & 36 \\
\hline Pride & 76 & 76 & 77 \\
\hline Request for salary increase & 50 & 42 & 57 \\
\hline Income (CZK) & 20,196 & 17,550 & 22,559 \\
\hline Individual approach & 46 & 46 & 47 \\
\hline Partner & 71 & 71 & 71 \\
\hline Age (years) & 39 & 39 & 39 \\
\hline One or more children & 67 & 72 & 62 \\
\hline Feeling of discrimination & 8 & 13 & 4 \\
\hline Great city & 23 & 24 & 22 \\
\hline
\end{tabular}

Note: $\mathrm{N}=1984,936,1048$

Source: elaborated by the authors or research 
Table 2 | Results of Models

\begin{tabular}{|c|c|c|c|c|}
\hline \multirow{2}{*}{$\begin{array}{l}\text { Explained } \\
\text { Variable } \\
\text { Eariablanatory }\end{array}$} & \multicolumn{2}{|c|}{ Intrinsic Rewards } & \multicolumn{2}{|c|}{ Level of Risk } \\
\hline & $\begin{array}{c}\text { Model } 1 \\
\text { Probit } \\
\text { Marginal effects }\end{array}$ & $\begin{array}{c}\text { Model } 2 \\
\text { Probit } \\
\text { Marginal effects }\end{array}$ & $\begin{array}{l}\text { Model } 3 \\
\text { OLS }\end{array}$ & $\begin{array}{l}\text { Model } 4 \\
\text { OLS }\end{array}$ \\
\hline Constant & $\begin{array}{l}2.674^{* * *} \\
(0.929)\end{array}$ & $\begin{array}{l}2.726^{* * *} \\
(0.931)\end{array}$ & $\begin{array}{c}-3.517^{* *} \\
- \\
\end{array}$ & $\begin{array}{c}-3.463^{* *} \\
(1.548)\end{array}$ \\
\hline Woman & $\begin{array}{c}0.056^{* *} \\
- \\
\end{array}$ & $\begin{array}{c}0.044^{* *} \\
- \\
\end{array}$ & $\begin{array}{l}-0.660^{* * *} \\
(0.111)\end{array}$ & $\begin{array}{c}-0.692^{* *} \\
(0.123) \\
\end{array}$ \\
\hline Secondary Education & $\begin{array}{c}0.136^{* *} \\
-\end{array}$ & $\begin{array}{c}0.135^{* *} \\
-\end{array}$ & - & $\begin{array}{l}- \\
-\end{array}$ \\
\hline School Diploma & $\begin{array}{l}0.262^{* * *} \\
- \\
\end{array}$ & $\begin{array}{c}0.263^{* * *} \\
- \\
\end{array}$ & $\begin{array}{l}0.351^{* * *} \\
(0.116)\end{array}$ & $\begin{array}{l}0.355^{* * * *} \\
(0.117) \\
\end{array}$ \\
\hline University Education & $\begin{array}{c}0.372^{* * *} \\
-\end{array}$ & $\begin{array}{l}- \\
-\end{array}$ & $\begin{array}{l}0.430^{* * *} \\
(0.145)\end{array}$ & - \\
\hline Time at Work & $\begin{array}{c}-0.003^{*} \\
-\end{array}$ & $\begin{array}{c}-0.003^{*} \\
-\end{array}$ & $\begin{array}{l}- \\
-\end{array}$ & $\begin{array}{l}- \\
-\end{array}$ \\
\hline Partner Works & $\begin{array}{c}0.053^{* *} \\
-\end{array}$ & $\begin{array}{l}0.053^{* *} \\
-\end{array}$ & $\begin{array}{l}-0.427^{* * *} \\
(0.163)\end{array}$ & $\begin{array}{l}-0.430^{* * *} \\
(0.163)\end{array}$ \\
\hline Preference Career & $\begin{array}{c}-0.079 * * * \\
-\end{array}$ & $\begin{array}{c}-0.079 * * * \\
-\end{array}$ & $\begin{array}{l}0.406^{* * *} \\
(0.110)\end{array}$ & $\begin{array}{l}0.407^{* * *} \\
(0.110)\end{array}$ \\
\hline Pride & $\begin{array}{c}0.045^{*} \\
- \\
\end{array}$ & $\begin{array}{c}0.044^{*} \\
- \\
\end{array}$ & $\begin{array}{l}0.324^{* * *} \\
(0.118)\end{array}$ & $\begin{array}{l}0.322^{* * *} \\
(0.118) \\
\end{array}$ \\
\hline $\begin{array}{l}\text { Request for Salary } \\
\text { Increase }\end{array}$ & $\begin{array}{c}-0.084^{* * *} \\
-\end{array}$ & $\begin{array}{c}-0.085^{* * *} \\
-\end{array}$ & $\begin{array}{c}0.645^{* * *} \\
-\end{array}$ & $\begin{array}{c}0.644^{* * *} \\
-\end{array}$ \\
\hline Income (log) & $\begin{array}{c}-0.130^{* * *} \\
- \\
\end{array}$ & $\begin{array}{c}-0.131^{* * *} \\
- \\
\end{array}$ & $\begin{array}{l}0.764^{* * *} \\
(0.158) \\
\end{array}$ & $\begin{array}{l}0.760^{* * *} \\
(0.158) \\
\end{array}$ \\
\hline Individual Approach & $\begin{array}{c}0.124^{* * *} \\
- \\
\end{array}$ & $\begin{array}{c}0.126^{* * *} \\
- \\
\end{array}$ & $\begin{array}{l}0.297^{* * *} \\
(0.102) \\
\end{array}$ & $\begin{array}{l}0.300^{* * *} \\
(0.103) \\
\end{array}$ \\
\hline Age 25-34 & - & - & $\begin{array}{l}0.251^{* *} \\
(0.106)\end{array}$ & $\begin{array}{l}0.248^{* *} \\
(0.106)\end{array}$ \\
\hline Partner & - & - & $\begin{array}{l}0.396^{* *} \\
(0.175) \\
\end{array}$ & $\begin{array}{l}0.399^{* *} \\
(0.175)\end{array}$ \\
\hline $\begin{array}{l}\text { Woman University- } \\
\text { educated }\end{array}$ & $\begin{array}{l}- \\
-\end{array}$ & $\begin{array}{c}0.349^{* * *} \\
-\end{array}$ & - & $\begin{array}{l}0.500^{* * *} \\
(0.189)\end{array}$ \\
\hline $\begin{array}{l}\text { Men University- } \\
\text { educated }\end{array}$ & $\begin{array}{l}- \\
-\end{array}$ & $\begin{array}{c}0.396^{* * *} \\
-\end{array}$ & - & $\begin{array}{l}0.362^{*} \\
(0.187)\end{array}$ \\
\hline Adj $R^{2}$ & 0.120 & 0.121 & 0.123 & 0.123 \\
\hline
\end{tabular}

Note: $\mathrm{N}=1984$; Adj $R^{2}$ is adjusted coefficient of determination.

Standard error of constant is given in brackets.

$* * * * *, *$ show the significance of the estimation at $1 \%, 5 \%$, and $10 \%$ level of significance.

Source: elaborated by the authors of research 


\section{References}

Alesina, A., Giuliano, P., Bisin, A. et al. (2011). Preferences for Redistribution, in Benhabib, J., Bisin, A., Jackson, M., eds., Handbook of Social Economics. North Holland, pp. 93-132. ISBN 978-0080932446 (e-book).

Atkinson, S., Baird, S., Frye, M. (2003). Do Female Mutual Fund Managers Manage Differently? Journal of Financial Research, 26(1), 1-18, https://doi.org/10.1111/1475-6803.00041

Barbulescu, R., Bidwell, M. (2013). Do Women Choose Different Jobs from Men? Mechanism of Application Segregation in the Market for Managerial Workers. Organization Science, 24(3), 737-756, https://doi.org/10.1287/orsc.1120.0757

Bertrand, M., Goldin, C., Katz, F. (2010). Dynamics of the Gender Gap for Young Professionals in the Financial and Corporate Sectors. American Economic Journal: Applied Economics, 2(3), 228-255, https://doi.org/10.1257/app.2.3.228

Betz, M., O'Connell, L. (1989). Work Orientation of Males and Females: Exploring the Gender Socialization Approach. Sociological Inquiry, 59(3), 318-330, https://doi.org/10.1111/ j.1475-682x.1989.tb00109.x

Blau, F., Kahn, L. (2016). The Gender Wage Gap: Extent, Trends, and Explanation. National Bureau of Economic Research. Cambridge, MA Working Paper No. 21913, https://doi.org/10.3386/ w21913

Bohnet, I. (2016). What Works: Gender Equality by Design. Harvard University Press. ISBN 978-0674089037.

Brožová, D., Stroukal, D. (2018). Gender Differences in Preference of the Wage Level and Risk on the Czech Labour Market. European Scientific Journal, 14(4), 73-90, https://doi. org/10.19044/esj.2018.v14n4p73

Croson, R., Gneezy, U. (2009). Gender Differences in Preferences. Journal of Economics Literature, 47(2), 448-474, https://doi.org/10.1257/jel.47.2.448

Daymont, T., Andrisani, P. (1984). Job Preferences, College Major, and the Gender Gap in Earnings. The Journal of Human Resources, 19(3), 408-428, https://doi. org/10.2307/145880

Goldin, C. (2014). A Grand Gender Convergence: Its Last Chapter. American Economic Review, 104(4), 1091-1119, https://doi.org/10.1257/aer.104.4.1091

Johnson, J., Powel, P. (1994). Decision Making, Risk and Gender: Are Managers Different? British Journal of Management, 5(2), 123-138, https://doi.org/10.1111/j.1467-8551.1994. tb00073.x

Marini, M. M., Fan, P.-L., Finley E. et al. (1996). Gender and Job Values. Sociology of Education, 69(1), 49-65, https://doi.org/10.2307/2112723

Miles, P. (2013). Why Do Educated, Successful Women Leave the Workforce? American International Journal of Social Science, 2(2).

Schurkov, O., Eckel, C. (2017). Gender Differences in Behavioral Traits and Labor Market Outcomes. Available at: https://www.wellesley.edu/sites/default/files/asset:economics/files/ schurkoveckelchapter201705.pdf

Tolbert, P., Moen, P. (1998). Men's and Women's Definition of "Good" Jobs: Similarities and Differences by Age and Across Time. Cornell University. Available at: http://digitalcommons. ilr.cornell.edu/articles 